\title{
Analisis Pengaruh Islamic Corporate Governance (ICG) dan Intellectual Capital (IC) terhadap Maqashid Syariah Indeks (MSI) pada Perbankan Syariah di Indonesia
}

\author{
Nono Hartono \\ Program Studi Ekonomi Syariah \\ Sekolah Tinggi Ekonomi Islam (STEI) Al-Ishlah Cirebon \\ Email: khalidbinwalid1435@gmail.com
}

\begin{abstract}
Abstrak
Sebagai suatu lembaga yang bergerak berdasarkan prinsip-prinsip syariah (bank syariah) tentunya memiliki karakteristik yang berbeda dari perusahaan lain dalam orientasi kinerjanya. Perbankan syariah dituntut untuk bekerja sesuai dengan prinsip dan etika bisnis syariah, salah satunya melalui penerapan tata kelola (Islamic Corporate Governance/ICG) dan pemanfaatan modal capital (Intellectual Capital/IC) agar dapat mencapai tujuan didirikannya bank syariah yaitu sesuai dengan maqashid syariah (diukur melalui Maqashid Syariah Indeks/MSI). Penelitian ini bertujuan untuk (1) mengetahui dan menganalisis pengaruh pengungkapan Islamic Corporate Governance (ICG) terhadap maqashid syariah indeks (MSI) pada perbankan syariah di Indonesia; dan (2) mengetahui dan menganalisis pengaruh Intellectual Capital (IC) terhadap maqashid syariah indeks (MSI) pada perbankan syariah di Indonesia. Metode yang digunakan dalam penelitian ini menggunakan pendekatan analisis isi untuk ICG, metode iB-VAIC untuk IC dan metode Sekaran pada perhitungan MSI. Sampel bank syariah yang digunakan berjumlah 11 Bank Umum Syariah (BUS) dari populasi 13 BUS pada periode tahun 2013-2017. Metode sampling yang digunakan dalam penentuan sampel adalah purposive sampling. Hasil penelitian menunjukkan bahwa baik ICG maupun iB-VAIC berpengaruh positif dan siginifikan terhadap MSI. Artinya pengungkapan item ICG dan pengelolaan ICakan berdampak pada peningkatan nilai MSI bank syariah.
\end{abstract}

Kata Kunci: Islamic Corporate Governance, Intellectual Capital, Maqashid Syariah Indeks 


\begin{abstract}
As an institution based on sharia principles (Islamic banks) certainly has differented characteristics from other companies in its performance orientation. Islamic banking is required to work in accordance with sharia business principles and ethics, one of which is through the implementation of governance (Islamic Corporate Governance/ICG) and the utilization of capital capital (Intellectual Capital/IC) in order to achieve the objectives of establishing Islamic banks in accordance with Islamic maqashid (measured through Maqashid Syariah Index/MSI). The objectives are (1) find out and analyze the effect of Islamic Corporate Governance (ICG) disclosures to maqashid syariah index (MSI) ofIndonesianIslamic banking; and (2) knowing and analyzing the influence of Intellectual Capital (IC) to maqashid syariah index (MSI) ofIndonesianIslamic banking. The method used content analysis approach for ICG, the $i B$-VAIC method for IC and Sekaran method on MSI calculations. The sample of Islamic banks was used 11 Islamic Commercial Banks (BUS) from a population of 13 BUS in the period 2013-2017. The sampling method wasused purposive sampling. The results showed that both ICG and iB-VAIC had positive and significant effects on MSI. This means that the disclosure of ICG items and IC management will have an impacted on increasing MSI value ofIslamic banks.
\end{abstract}

Keywords: Islamic Corporate Governance, Intellectual Capital, Maqashid Syariah Index 


\section{Pendahuluan}

Perkembangan industri perbankan syariah di Indonesia saat ini sudah mengalami peningkatan yang cukup pesat dan sudah memiliki tempat yang memberikan cukup pengaruh dalam lingkungan perbankan nasional.Sesuai dengan data statistik perbankan syariah posisi Januari 2018, telah terdapat 13 Bank Umum Syariah (BUS), 21 Unit Usaha Syariah (UUS), serta 167 Bank Pembiayaan Rakyat Syariah (BPRS) di Indonesia. Bertambahnya BUS di Indonesia tidak terlepas dengan perkembangan aset yang dimilikinya. Perkembangan aset, jumlah pembiayaan dan dana pihak ketiga perbankan syariah yang mengalami peningkatan di setiap tahunnya. Pertumbuhan aset, pembiayaan dan dana pihak ketiga selama 3 (tiga) tahun terakhir masing-masing sebesar $0,95 \%, 10,13 \%$ dan $13,02 \%$.

Sebagai suatu lembaga yang bergerak berdasarkan prinsip-prinsip syariah, bank syariah tentunya memiliki karakteristik yang berbeda dari perusahaan lain dalam orientasi kinerjanya. Perbankan syariah dituntut untuk bekerja sesuai dengan prinsip dan etika bisnis syariah dengan menerapkan tata kelola (corporate governance) yang transparan dan akuntabel. Bentuk corporate governance pada bank syariah adalah Islamic Corporate Governance (ICG) (Farook et al. 2012). Implementasi ICG pada bank syariah akan memberikan indikasi dan kesan kepada masyarakat bahwa lembaga keuangan syariah terhindar dari praktik kecurangan, walaupun kecurangan sendiri dapat terjadi dimana saja (Maradita, 2014).

Berikut dipaparkan beberapa penelitian pengaruh IC terhadap kinerja keuangan seperti yang dilaporkan oleh Andraeny dan Putri (2017), variabel IC dan dewan pengawas syariah (sharia supervisory board) memiliki pengaruh positif dan signifikan terhadap kinerja keuangan. Hal yang sama juga dilaporkan oleh Hidayanti (2017); Prasetya dan Mutmainah (2010); Ulum (2007) dan Chen et al. (2005).
Selain dihadapkan pada penerapan ICG, perbankan syariah juga menghadapi permasalahan dalam mengelola dan mengalokasikan sumber dayanya. Menurut Solikhah et al. (2010), para pelaku bisnis mulai menyadari bahwa kemampuan bersaing tidak hanya terletak pada kepemilikan aset berwujud, tetapi lebih pada inovasi, sistem informasi, pengelolaan organisasi dan sumber daya manusia yang dimilikinya. Sehingga, perusahaanperusahaan mengubah strategi bisnisnya dari bisnis yang didasarkan pada tenaga kerja (labor based business) menjadi bisnis yang berdasarkan pada pengetahuan (knowledgebased business) atau juga disebut sebagai aset tidak berwujud (intangible assets). Salah satu pendekatan yang digunakan dalam penilaian dan pengukuran intangible asset tersebut adalah intellectual capital (IC). Menurut Stewart (1997), IC adalah:

"Intellectual capital adalah materi intelektual (pengetahuan, informasi, properti intelektual, pengalaman yang dapat digunakan untuk menciptakan kekayaan. Ini adalah suatu kekuatan akal kolektif atau seperangkat pengetahuan yang berdaya guna".

Bontis et al. (2000) menyatakan bahwa secara umum, para peneliti mengidentifikasi tiga konstruk utama dari IC, yaitu: human capital (HC), structural capital (SC), dan customer capital (CC). Menurut Sawarjuwono (2003), perusahaanperusahaan di Indonesia cenderung menggunakan conventional based dalam membangun bisnisnya, sehingga produk yang dihasilkannya masih miskin kandungan teknologi.

Beberapa penelitian terdahulu melaporkan bahwa bahwa ICG berpengaruh terhadap kinerja keuangan. Asrori (2014) yang meneliti tentang implementasi ICG dan implikasinya terhadap kinerja bank syariah, yang menunjukkan hasil ICG berpengaruh terhadap kinerja bank syariah. El Junusi (2012) yang meneliti mengenai implementasi sharia governance dan implikasinya 
terhadap reputasi dan kepercayaan bank syariah, yang menunjukkan hasil bahwa pengimplementasian sharia governance berpengaruh terhadap reputasi dan kepercayaan nasabah yang secara langsung berkaitan dengan kinerja keuangan bank syariah.

Perbankan syariah pada sekarang ini juga dihadapkan pada kurangnya alat pengukuran kinerja keuangan yang sesuai dengan karakteristik bank syariah. Sebagai solusinya, banyak peneliti yang mengukur kinerja bank syariah dengan menggunakan pendekatan ukuran kinerja bank konvensional melalui rasio-rasio keuangan. Untuk itu Mohammed, Dzuljastri dan Taif (2008) mengembangkan pengukuran kinerja keuangan bank syariah berdasarkan maqashid syariah dalam jurnal yang berjudul "The Performance Measures of Islamic Banking Based on the Maqashid Framework" menjadi solusi untuk mengukur kinerja bank syariah. Selanjutnya model MSI tersebut banyak digunakan oleh peneliti lainnya untuk mengukur kinerja bank syariah berdasarkan konsep maqashid syariah.

Berdasarkan latar belakang tersebut penelitian ini bertujuan (1) mengetahui dan menganalisis pengaruh pengungkapan Islamic Corporate Governance (ICG) terhadap maqashid syariah indeks (MSI) pada perbankan syariah di Indonesia; dan (2) mengetahui dan menganalisis pengaruh Intellectual Capital (IC) terhadap maqashid syariah indeks (MSI) pada perbankan syariah di Indonesia.

\section{Telaah Teori \\ Islamic Corporate Governance (ICG)}

Bhatti dan Bhatti 2010 dalam Asrori

(2014) memberikan istilah corporate governance dalam perspektif Islam dengan ICG. Penelitian ini juga menggunakan istilah ICG untuk menggambarkan corporate governance dalam perspektif islam pada bank syariah. ICG mencoba untuk mengarahkan agen-agen ekonomi, sistem hukum, dan corporate governance kepada nilai-nilai moral dan sosial berdasarkan hukum syariah. Berbagai kegiatan ekonomi, perusahaan, dan bisnis didasarkan pada paradigma etrhoreligious dengan tujuan tunggal yaitu kesejahteraan individu dan masyarakat secara keseluruhan. Pada dasarnya, ICG memiliki kesamaan tujuan dengan corporate governance pada umumnya, namun ICG mengacu pada nilai agama Islam. ICG mencoba untuk memadukan antara hukum Islam dengan model stakeholder dalam corporate governance.

Menurut Menurut Larbsh (2015) terdapat dua sifat dari ICG. Pertama, seluruh aspek kehidupan, etika, dan sosial perusahaan harus mengacu pada hukum Islam. Kedua, ICG juga harus mengacu pada etika bisnis dan prinsip-prinsip ekonomi dan keuangan Islam diantaranya terkait dengan perintah zakat, pelarangan riba, larangan spekulasi, dan perintah untuk mengembangkan sistem ekonomi berdasarkan profit and loss sharing.

\section{Intellectual Capital (IC)}

Terdapat banyak pakar yang telah menguraikan definisi dari IC. Definisi IC ini juga ditemukan di beberapa literatur dengan berbagai macam definisi dan dengan berbagai kompleksitas. Menurut Brooking (1996) dalam Ulum (2009) menyatakan bahwa:

"IC adalah istilah yang diberikan untuk mengkombinasikan aset tidak berwujud dari pasar, properti intelektual, infrastruktur, dan manusia yang menjadikan suatu perusahaan dapat berfungsi dan beroperasi”.

Tom Stewart (1991) dalam Ulum (2009), mendefinisikan IC sebagai berikut:

"IC merupakan materi intelektual (pengetahun informasi, property intelektual pengalaman) yang dapat digunakan untuk menciptaka kekayaan. Ini adalah suatu kekuatan akal kolektif atau seperangkat pengetahuan yang berdaya guna".

Bornemann et al. (1999) dalam Ulum (2009) mengklasifikasikan indikator dari IC menjadi tiga kategori. Ketiga kategori tersebut yaitu human capital, customer capital, dan structural capital. Kategori 
human capital meliputi pengetahuan (knowledge), keterampilan (skill), motivasi (motivation), dan hubungan dalam tim (relation). Kategori kedua yaitu customer capital, kategori ini disebut juga stakeholder relationships. Kategori ini meliputi hubungan perusahaan dengan pelanggan dan hubungan perusahaan dengan pemasok. Sedangkan kategori yang ketiga adalah structural capital. Structural capital meliputi manajemen perusahaan seperti database, struktur organisasi, dan prosedur-prosedur yang superior. Selain dari ketiga kategori tersebut, terdapat satu kategori tambahan yang disarankan yaitu image atau reputation capital. Kategori inilah yang mampu mempengaruhi kategori yang lainnya.

\section{Maqashid Syariah Indeks (MSI)}

MSI merupakan metode pengukuran kinerja perbankan syariah yang dikembangkan oleh Mohammed, Dzuljastri dan Taif (2008). Dalam penelitian mereka yang berjudul "The Performance Measures of Islamic Banking Based on the Maqashid Framework" dirumuskan evaluasi kinerja untuk perbankan syariah yang mengacu pada konsep maqashid syariah. Pengembangan MSI didasari oleh ketidaksesuaian penggunaan indikator kinerja konvensional di perbankan syariah. Ketidaksesuaian tersebut disebabkan oleh berbedanya tujuan antara indikator konvensional yang menitikberatkan hanya pada pengukuran keuangan sedangkan tujuan perbankan syariah bersifat multi dimensional

Konsep Maqashid Syariah Abu Zahrah dalam kitab Ushul Fiqihnya merumuskan konsep maqashid syariah dengan mengklasifikasikannya ke dalam tiga tujuan utama yaitu :
a. Tahdzib al fard (Pendidikan individu)
b. Iqamah al-adl (Menegakkan keadilan)
c. Jalb al maslahah (Mewujudkan kemaslahatan/Kepentingan Umum)

Ketiga konsep di ataslah yang dikembangkan oleh Mohammed dan Taib
(2015), sebagai pijakan dalam mengembangkan MSI.

1. Tahzibul Fardi (Mendidik Individu), dimensinya antara lain:

a. (D1) Advancement Knowledge. Bank syariah dituntut untuk ikut berperan serta dalam mengembangkan pengetahuan tidak hanya pegawainya tetapi juga masyarakat banyak. Peran ini dapat diukur melalui elemen seberapa besar bank syariah memberikan beasiswa pendidikan (Education Grant) dan melakukan penelitian dan pengembangan (Research). Rasio pengukurannya dapat diukur melalui seberapa besar dana beasiswa terhadap total pendapatannya (Education Grant/ Total Expense) dan rasio biaya penelitian terhadap total biayanya (Research Expense/Total expense).

b. (D2) Instilling New Skill and Improvement. Bank syariah memiliki kewajiban untuk meningkatkan skill dan pengetahuan pegawainya, hal ini ditunjukkan dengan seberapa besar perhatian bank syariah terhadap pelatihan dan pendidikan bagi pegawainya (Training).

c. (D3) Creating Awareness of Islamic Banking. Peran bank syariah dalam meningkatkan pengetahuan masyarakat khususnya tentang perbankan syariah adalah dengan melakukan sosialisasi dan publisitas perbankan syariah dalam bentuk informasi produk bank syariah, operasional dan sistem ekonomi syariah (Publicity).

\section{Iqamah al Adl (Menegakan} Keadilan), dimensinya antara lain:

a. (D4) Fair Returns. Bank syariah dituntut untuk dapat melakukan transaksi secara adil yang tidak merugikan nasabahnya. Salah satu yang dapat dilakukan adalah 
dengan memberikan hasil yang adil dan setara (fair return).

b. (D5) Cheap Products and Services. Elemen pengukuran yang dilakukan adalah E6. Functional Distribution dengan rasio kinerja pengukuran ( $R 6$. Mudharabah or Musyarakah Modes / Total Investment Mode), berapa besar pembiayaan dengan skim bagi hasil mudharabah dan musyarakah terhadap seluruh model pembiayaan yang diberikan bank syariah.

c. (D6) Elimination of Injustices.Bank syariah dituntut untuk menjalankan aktivitas perbankan khususnya investasi yang dilakukan terbebas dari riba. Semakin tinggi rasio investasi yang bebas riba terhadap total investasinya, akan berdampak positif terhadap berkurangnya kesenjangan pendapatan dan kekayaan dalam kehidupan bermasyarakat. Hal ini dapat diukur melalui rasio Interest free income terhadap total income.

3. Maslahah (Public Interest), dimensi pengukurannya antara lain:

a. (D7) Profitability of Bank.

Semakin besar keuntungan yang diperoleh bank syariah maka akan berdampak pada peningkatan kesejahteraan tidak hanya pemilik dan pegawai bank syariah tetapi dapat berdampak pada semua stakeholder perbankan syariah.

b. (D8) Redistribution of Income and Wealth. Salah satu peran penting keberadaan bank syariah adalah untuk mendistribusikan kekayaan pada semua golongan. Peran ini dapat dilakukan bank syariah melalui pendistribusian dana zakat yang dikeluarkan oleh bank syariah.

c. (D9) Investment in Real Sector. Keberadaan bank syariah diharapkan untuk mendorong pertumbuhan sektor riil yang selama ini tidak seimbang dengan sektor keuangan. Prinsip dan akadakad bank syariah dinilai lebih sesuai dalam pengembangan sektor rill, sehingga tingkat pembiayaan bank syariah diharapkan lebih banyak pada sektor riil tersebut seperti sektor pertanian, pertambangan, konstruksi, manufaktur dan usaha mikro. Salah satu cara pengukuran yang dilakukan untuk melihat seberapa besar pembiayaan bank syariah terhadap sektor-sektor riil dibandingkan dengan total pembiayaan bank tersebut.

\section{Metodologi \\ Desain Penelitian}

Desain penelitian ini bersifat studi eksplorasi, dimana data diperoleh dan dianalisis melalui secara kuantitatif.

\section{Pemilihan Sampel dan Data Penelitian}

Pemilihan sampel dalam penelitian ini menggunakan metode purposive sampling dengan tujuan untuk mendapatkan sampel yang representative sesuai dengan kriteria yang ditentukan oleh peneliti. Menurut (Arikunto, 2010) pengambilan sampel dengan metode ini cukup baik karena sesuai dengan pertimbangan peneliti sendiri sehingga dapat mewakili populasi.

Adapun kriteria sampel yang akan digunakan dalam penelitian ini adalah sebagai berikut: (1) Bank Umum Syariah yang beroperasi di Indonesia, dan (2) Bank Umum Syariah secara konsisten menyajikan laporan tahunan (annual report) publikasi periode 2013-2017 di website resmi masingmasing bank. Berdasarkan kriteria pemilihan sampel tersebut diperoleh bank syariah yang dijadikan sampel penelitian ini berjumlah 11 bank syariah.

Jenis data yang digunakan dalam penelitian ini adalah data sekunder. Menurut Umar (2007) data sekunder merupakan data primer yang diolah lebih lanjut dan disajikan 
oleh pihak pengumpul data primer atau oleh pihak lain. Data sekunder yang dimaksud dalam penelitian ini adalah laporan tahunan (annual report) bank syariah periode 20132017 yang telah dipublikasi di website resmi masing-masing bank. Sedangkan laporan tahunan yang dimaksud dalam penelitian ini mencakup laporan keuangan, laporan manajemen, dan laporan pelaksanaan GCG yang menjadi satu kesatuan dalam sebuah laporan atau yang berdiri sendiri.

\section{Operasional Variabel Penelitian}

Terdapat duam variabel yang digunakan penelitian dalam penelitian ini, yaitu variabel konstruk independen dan variabel konstruk dependen. Variabel konstruk indepenen dalam penelitian ini adalah pengungkapan Islamic Corporate Governance/ICG (X1) danIntellectual Capital (IC) yang selanjutnya ditulis dengan Islamic Banking - Value Added Intellectual Coefficient (iB-VAIC), sedangkan variabel konstruk dependen adalah maqashid syariah indeks (Y).

\section{Variabel Konstruk Eksogen : ICG dan IC Islamic Corporate Governance (ICG)}

Indeks pengungkapan ICG dalam penelitian ini dikembangkan dari standar corporate governance lembaga keuangan syariah internasional yang dikeluarkan oleh IFSB. ICG dalam penelitian ini yang mencakup dua kategori utama yaitu Sharia Governance (SG) dan General Governance (GG). SG terdiri 3 dimensi yaitu Dewan Pengawas Syariah, Unit Internal Syariah Compliance, dan Unit Internal Sharīah Review/audit yang menggambarkan sistem tatakelola syariah. Sedang GG terdiri dari 7 dimensi yang menggambarkan sistem tatakelola bank syariah secara umum yaitu dewan komisaris, dewan direksi, dewan komite, internal kontrol dan eksternal audit, manajemen resiko, Investment Account Holders (IAH) dan pelaporan CG. Sehingga total ICG terdiri dari 8 dimensi yang mencakup 58 item pengungkapan.

Tabel 1

Indeks Pengungkapan ICG

\begin{tabular}{|c|c|c|c|}
\hline No & Dimensi Pengungkapan & $\begin{array}{c}\text { Item } \\
\text { Variabel }\end{array}$ & $\begin{array}{c}\text { Jumlah } \\
\text { Item }\end{array}$ \\
\hline A & Sharia Governance & & \\
\hline 1 & Dewan Pengawas Syariah (Shariah Supervisory Board) & (X11) & 9 \\
\hline 2 & $\begin{array}{l}\text { Unit Kepatuhan Syariah Internal (Internal Shariah } \\
\text { Compliance Unit) }\end{array}$ & $(\mathrm{X} 12)$ & 3 \\
\hline 3 & $\begin{array}{l}\text { Unit Audit Syariah Internal (Internal Sharīah Review/audit } \\
\text { Unit) }\end{array}$ & $(\mathrm{X} 13)$ & 3 \\
\hline B & General Governance & & \\
\hline 4 & Dewan Direktur (Board of Director ) & $(\mathrm{X} 14)$ & 7 \\
\hline 5 & Dewan Komite (Board Committees) & $(\mathrm{X} 15)$ & 10 \\
\hline 6 & $\begin{array}{l}\text { Internal Kontrol dan Internal Audit (Internal Control dan } \\
\text { External Audit) }\end{array}$ & $(\mathrm{X} 16)$ & 7 \\
\hline 7 & Manajemen Risiko (Risk Management) & $(\mathrm{X} 17)$ & 10 \\
\hline 8 & Investment Account Holders (IAH) & $(\mathrm{X} 18)$ & 9 \\
\hline & Jumlah & & 58 \\
\hline
\end{tabular}

Selanjutnya setelah ditentukan item, dilakukan skoring yaitu dengan memberikan skor pada setiap indeks yang diungkapkan pada laporan tahunan (annual report) bank syariah. Jika terdapat sub-item yang diungkapkan maka akan mendapat skor "1", dan jika tidak maka akan mendapat skor " 0 ". 
Rumus yang digunakan untuk pengungkapan indeks ICG adalah sebagai
menentukan seberapa besar tingkat berikut:

$$
\text { Indeks ICG }=\frac{\text { Jumla h Sub-Item yang diungkapkan }}{\text { Jumla } h \text { Skor Maksimal (58) }} \times 100 \%
$$

\section{Intellectual Capital (IC)}

Teknik perhitungan model IC yang digunakan untuk mengukur kinerja perbankan syariah dalam penelitian ini dikenal sebagai Islamic Banking Value Added Intellectual Coefficient (iB-VAIC). iB-VAIC dikembangkan oleh Ulum (2009) dan merupakanhasil modifikasi dari model yang telah ada yaitu VAIC $^{\mathrm{TM}}$ yang disusun oleh Pulic (1998). Perhitungan iB-VAIC terdapat empat tahapan, yaitu:

Tahap pertama dengan menghitung iBValue Added (iB-VA)

IB-VA dihitung dengan menggunakan cara yaitu sebagai berikut :

$$
\text { iB-VA = OUT - IN }
$$

Keterangan:

$\mathrm{iB}-\mathrm{VA}=$ Islamic BankingValue Added

OUT = Output (total pendapatan)

IN = Input (total beban selain beban karyawan)

\section{Menghitung iB-Value Added Capital} Employed (iB-VACA)/X21

iB-VACA adalah indikator untuk iB-

VA yang diciptakan oleh satu unit dari human capital. Rasio ini menunjukkan kontibusi yang dibuat oleh setiap unit dari CE terhadap value added perusahaan.

Keterangan:

$$
i B-V A C A=\frac{V A}{C E}
$$

iB-VACA : Islamic Banking Value Added Capital Employed

iB-VA : Islamic Banking Value added

CE : Capital Employed: dana yang tersedia (total ekuitas)

\section{Menghitung iB-Value Added Human Capital (iB-VAHU) /X22}

iB-VAHU menunjukkan berapa banyak iB-VA dapat dihasilkan dengan dana yang dikeluarkan untuk tenaga kerja. Rasio ini menunjukkan kontribusi yang dibuat oleh setiap rupiah yang diinvestasikan dalam $\mathrm{HC}$ terhadap value added organisasi.

Keterangan

$$
\boldsymbol{i B}-\boldsymbol{V A H U}=\frac{\boldsymbol{V A}}{\boldsymbol{H C}}
$$

iB-VAHU : Islamic Banking Value added Human Capital

iB-VA : Islamic BankingValue added

HC : Beban karyawan (Human capital)

\section{Menghitung iB-Structural Capital Value Added (iB-STVA) /X23}

Rasio ini mengukur jumlah SC yang dibutuhkan untuk menghasilkan satu rupiah dari iB-VA dan merupakan indikasi bagaimana keberhasilan SC dalam penciptaan nilai.

$$
i B-S T V A=\frac{S C}{V A}
$$

Keterangan

iB-STVA : Islamic Banking Structural Capital Value Added

SC : Structural capital (iB-VA $\mathrm{HC})$

IB-VA : Value Added

\section{Menghitung iB-Value Added Intellectual Coefficient (iB-VAIC ${ }^{\mathrm{TM}}$ )}

iB-VAICTM

mengindikasikan kemampuan intelektual organisasi yang dapat juga dianggap sebagai BPI (Business Performance Indikator). $\mathrm{iB}-\mathrm{VAIC} \mathrm{CM}^{\mathrm{TM}}$ merupakan penjumlahan dari tiga komponen sebelumnya, yaitu iB-VACA, iB-VAHU, dan iB-STVA.

$$
\begin{aligned}
& \text { iB-VAIC }{ }^{\mathbf{M}}=\mathbf{i B}-\mathbf{V A C A}+\mathbf{I B}-\mathbf{V A H U}+\mathbf{i B - S T V A} \\
& \text { Untuk dapat dilakukan } \\
& \text { pemeringkatan terhadap sejumlah perbankan, } \\
& \text { hasil perhitungan iB-VAIC dapat diranking } \\
& \text { berdasarkan skor yang dimiliki, yaitu: }
\end{aligned}
$$


1. Top performers - skor $\mathrm{VAIC}^{\mathrm{TM}}$ di atas 3,00

2. Good performers - skor VAIC ${ }^{\mathrm{TM}}$ antara 2,0 sampai 2,99

3. Common performers - skor $\mathrm{VAIC}^{\mathrm{TM}}$ antara 1,5 sampai 1,99

4. Bad performers - skor VAIC ${ }^{\mathrm{TM}}$ di bawah 1,5
Variabel Konstruk Endogen : Maqashid Syariah Indeks (MSI)

Dalam menyusun pendekatan MSI, Mohammed, Dzuljastri dan Taif (2008) menggunakan metode metode Sekaran untuk menentukan indikator pengukuran. Untuk mendapatkan hasil yang terbaik dari pengukuran MSI, maka dilakukan verifikasi dari model dan pembobotan pada setiap konsep dan elemen pengukuran seperti yang disajikan pada Tabel

Tabel 2

Bobot Rata-Rata Tujuan dan Elemen Pengukuran Maqashid Syariah

\begin{tabular}{lclc}
\hline \multicolumn{1}{c}{$\begin{array}{c}\text { Konsep } \\
\text { (Tujuan) }\end{array}$} & $\begin{array}{c}\text { Bobot rata-rata } \\
(100 \%)^{*}\end{array}$ & \multicolumn{1}{c}{ Elemen } & $\begin{array}{c}\text { Bobot rata-rata } \\
(100 \%)\end{array}$ \\
\hline Pendidikan & 30 & Donasi beasiswa & 24 \\
Individu (Y11) & & Penelitian & 27 \\
& & Pelatihan & 26 \\
& & Publikasi & 23 \\
Menciptakan & \multirow{2}{*}{41} & Total & 100 \\
Keadilan (Y12) & & Pengembalian yang adil & 30 \\
& & Fungsi distribusi & 32 \\
Kepentingan & \multirow{2}{*}{29} & Produk bebas bunga & 38 \\
Umum (Y13) & & Total & 100 \\
& & Rasio profit & 30 \\
& & Pendapatan personal & 33 \\
& & Investasi di sektor rill & 37 \\
\hline
\end{tabular}

Sumber : Mohammed dan Taib (2015)

Ada tiga tahap yang akan dilakukan untuk mengukur kinerja maqashid syariah bank syariah, yaitu:

1. Menilai setiap rasio kinerja maqashid syariah

2. Menentukan peringkat dari bank syariah berdasarkan Indikator Kinerja (IK). Proses menentukan peringkat darisetiap bank syariah dilakukan melalui IK setiap bank syariah. Proses tersebut menggunakan Simple Additive Weighting Method (SAW) dengan cara pembobotan, agregat dan proses menentukan peringkat (weighting, aggregating and ranking processes). Konsep dasar metode SAW adalah mencari penjumlahan terbobot dari rating setiap tujuan pada semua atribut yang disebut dengan Multiple Attribute Decision Making (MADM).Secara matematis, proses menentukan indikator kinerja dan tingkat indeks maqasid syariah tersebut dapat dijelaskan sebagai berikut (Mohammed, Dzuljastri dan Taif, 2008):

\section{a. Mendidik Individu (Tahzib al-Fard) \\ Tujuan 1 (T1) Indikator Kinerja (IK) untuk Tujuan 1 sebagai berikut:}

$$
I K(T 1)=W_{1}^{1}\left(E_{1}^{1} x R_{1}^{1}+E_{1}^{2} x R_{1}^{2}+E_{1}^{3} x R_{1}^{3}+E_{1}^{4} x R_{1}^{4}\right)
$$

Dimana: 
$\mathrm{T} 1=$ Tujuan pertama dari Maqashid Syariah (Tahzib al Fard)

$W_{l}{ }^{1}=$ Bobot rata-rata untuk tujuan pertama (Tahzib al Fardi)

$E_{l}{ }^{1}=$ Bobot rata-rata untuk elemen pertama tujuan 1 (E1. Donasi beasiswa)

$E_{l}^{2}=$ Bobot rata-rata untuk elemen kedua tujuan 1 (E2. Penelitian)

$E_{l}^{3}=$ Bobot rata-rata untuk elemen ketiga tujuan 1 (E3. Pelatihan)

$E_{l}{ }^{4}=$ Bobot rata-rata untuk elemen ke empat tujuan 1 (E4. Publikasi)

$R_{l}{ }^{1}=$ Rasio kinerja untuk elemen pertama tujuan 1

$R_{I}^{2}=$ Rasio kinerja untuk elemen kedua tujuan 1

$R_{I}^{3}=$ Rasio kinerja untuk elemen ketiga tujuan 1

$R_{1}{ }^{4}=$ Rasio kinerja untuk elemen ke empat tujuan 1

b. Menciptakan

Keadilan(Iqamah al-Adl)
Tujuan 2 (T2) Indikator Kinerja (IK) untuk Tujuan 2 sebagai

berikut:

$$
I K(T 2)=W_{2}^{2}\left(E_{2}^{1} \times R_{2}^{1}+E_{2}^{2} x R_{2}^{2}+E_{2}^{3} x R_{2}^{3}\right)
$$

Dimana:

$\mathrm{T} 2=$ Tujuan kedua dari Maqashid Syariah (Iqamah al-Adl)

$W_{2}^{2}=$ Bobot rata-rata untuk tujuan kedua (Iqamah al-Adl)

$E_{2}{ }^{1}=$ Bobot rata-rata untuk elemen pertama tujuan 2 (E1. Pengembalian yang adil)

$E_{2}^{2}=$ Bobot rata-rata untuk elemen kedua tujuan 2 (E2. Fungsi distribusi)

$E_{2}{ }^{3}=$ Bobot rata-rata untuk elemen ketiga tujuan 2(E3. Produk bebas bunga)

$R_{2}{ }^{1}=$ Rasio kinerja untuk elemen pertama tujuan 2

$R_{2}{ }^{2}=$ Rasio kinerja untuk elemen kedua tujuan 2

$R_{2}{ }^{3}=$ Rasio kinerja untuk elemen ketiga tujuan 2

\section{c. Kepentingan Umum (Jalb al} Maslahah)
Tujuan 3 (T3) Indikator Kinerja (IK) untuk Tujuan 3 sebagai

berikut:

$$
I K(T 3)=W_{3}^{3}\left(E_{3}^{1} x R_{3}^{1}+E_{3}^{2} x R_{3}^{2}+E_{3}^{3} x R_{3}^{3}\right)
$$

\section{Dimana:}

$\mathrm{T} 3=$ Tujuan ketiga dari Maqashid Syariah (Jalb al Maslahah)

$W_{3}{ }^{3}=$ Bobot rata-rata untuk tujuan kedua (Jalb al Maslahah)

$E_{3}{ }^{1}=$ Bobot rata-rata untuk elemen pertama tujuan 3 (E1. Rasio profit)

$E_{3}{ }^{2}=$ Bobot rata-rata untuk elemen kedua tujuan 3 (E2. Pendapatan personal)

$E_{3}{ }^{3}=$ Bobot rata-rata untuk elemen ketiga tujuan 3 (E3. Investasi di sektor rill)

$R_{3}{ }^{1}=$ Rasio kinerja untuk elemen pertama tujuan 3

$R_{3}{ }^{2}=$ Rasio kinerja untuk elemen kedua tujuan 3

$R_{3}{ }^{3}=$ Rasio kinerja untuk elemen ketiga tujuan 3

3. Menghitung maqasid syariah menghitung maqasidindeks indeks. Tahap selanjutnya adalah dengan rumus sebagai berikut:

$$
\text { MSI = IK (T1) + IK (T2) + IK (T3) }
$$

Dimana: 


$\begin{aligned} \text { MSI } & \text { Nilai indeks maqasid syariah } \\ \text { IK (T1) }= & \text { Total indikator kinerja untuk tujuan pertama (mendidik } \\ \text { individu) } & \begin{array}{l}\text { Total indikator kinerja untuk tujuan kedua (menciptakan } \\ \text { keadilan) }\end{array} \\ \text { IK (T2) } & \text { Total indikator kinerja untuk tujuan ketiga (kepentingan umum) }\end{aligned}$

\section{Pengujian Empiris}

Analisis data dilakukan dengan metode Partial Least Square (PLS). PLS adalah metode penyelesaian structural equation modelling (SEM) yang dalam hal ini (sesuai tujuan penelitian) lebih tepat dibandingkan dengan teknik-teknik SEM lainnya. Jumlah sample yang kecil, potensi distribusi variabel tidak normal,dan penggunaan indikator formative dan refleksive membuat PLS lebih sesuaiuntuk dipilih dibandingkan dengan misalnya, maximum likelihood SEM (Ghozali, 2014). Terdapat dua bagian analisis yang harus dilakukan dalam PLS, yaitu:

\section{Evaluasi Model Pengukuran (Outer Model)}

Outer model menentukan spesifikasi hubungan antara konstruk laten dengan indikatornya. Persamaan untuk outer modelmenurut Yamin dan Kurniawan (2009) yaitu:

$$
\begin{aligned}
& X=\pi_{x} \xi+\varepsilon_{x} \\
& X=\pi_{y} \eta+\varepsilon_{y}
\end{aligned}
$$

Dalam penelitian ini model indikator yang digunakan adalah model reflektif. Model reflektif mengasumsikan bahwa konstruk atau variabel laten mempengaruhi indikator, dimana arah hubungan kausalitas dari konstruk ke indikator atau manifes (Ghozali, 2014). Dalam pengukuran outer model indikator refleksif digunakan tiga kriteria untuk menilai outer model, yaitu convergent validity, composite reliability dan discriminant validity.

\section{Evaluasi Model Struktural (Inner Model)}

Inner Model menentukan spesifikasi hubungan antara konstruk laten dan konstruk laten lainnya. Persamaan dari inner model menurut Yamin dan Kurniawan (2009) adalah:

$$
\eta=\eta \beta+\xi \Gamma+\zeta
$$

\section{Ket:}

$\eta=$ Matriks konstruk laten endogen $\xi=$ Matriks konst rak laten eksogen

$\beta=$ Koefisien matriks variabel endogen

$\Gamma=$ Koefisien matriks variabel eksogen

$\zeta=$ Inner model residual matriks

Evaluasi model struktural (inner model) meliputi uji kecocokan model (model fit), path coefficient, dan R2 . Uji model fit ini digunakan untuk mengetahui apakah suatu model memiliki kecocokan dengan data. Pada uji kecocokan model terdapat 3 indeks pengujian, yaitu average path coefficient(APC), average $R$-squared (ARS) dan average varians factor (AVIF). Nilai $\mathrm{p}$ untuk APC dan ARS harus lebih kecil dari 0.05 atau berarti signifikan. Selain itu, AFIV sebagai indikator multikolinearitas harus lebih kecil dari 5 (Sholihin dan Ratmono, 2013). 
3. Hipotesis

Uji hipotesis digunakan untuk menjelaskan arah hubungan antara variabel independen dan variabel dependennya. Pengujian ini dilakukan atas model dari
Structural Equation Modelling (SEM) melalui pendekatan Partial Least Square (PLS). Program yang digunakan adalah SmartPLS 3.0. Berikut disajikan model SEM

\section{Gambar 1}

\section{Model SEM}

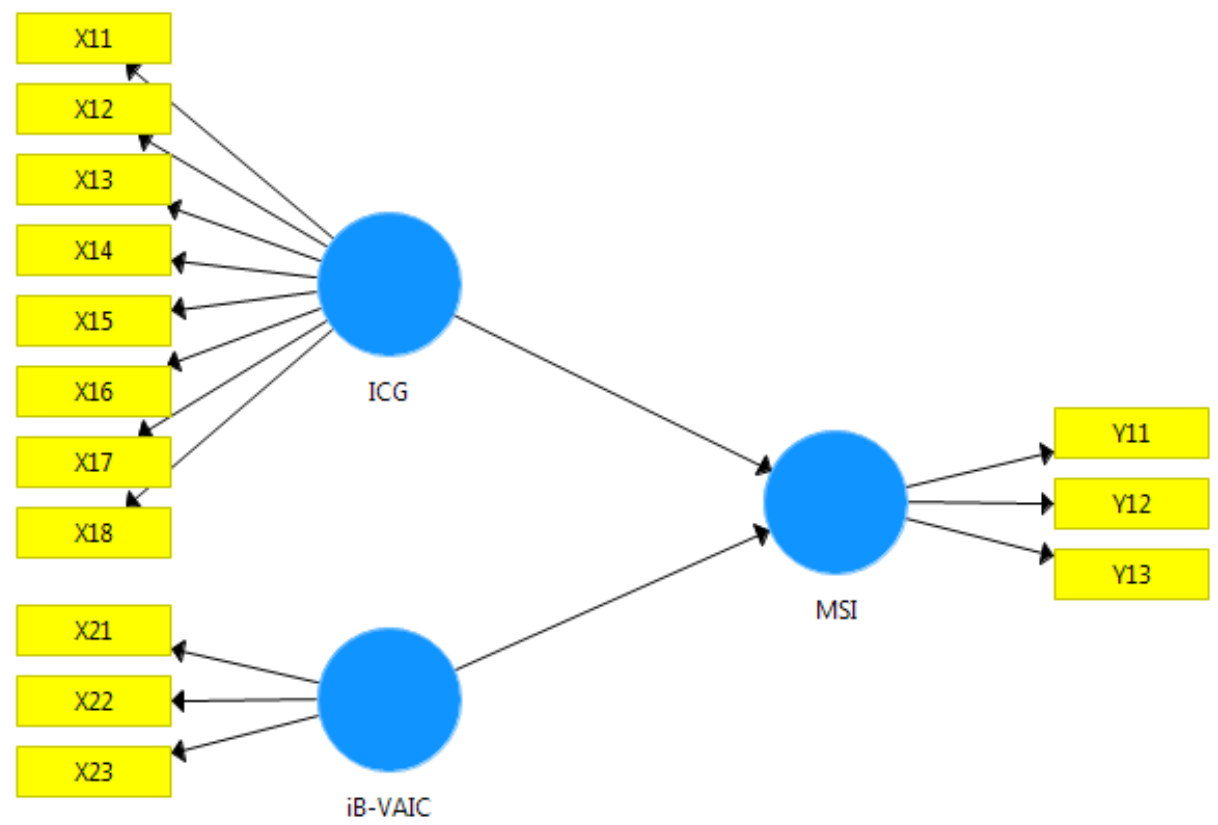

Sumber : Data penelitian diolah (2018)

Hipotesis penelitian iniadalah:

$\mathrm{Ho}_{1}$ : ICG tidak berpengaruh positif dan signifikan terhadap MSIbank syariah di Indonesia

$\mathrm{Ha}_{1}$ : ICG berpengaruh positif dan signifikan terhadap MSI bank syariah di Indonesia

$\mathrm{Ho}_{2}$ : iB-VAIC tidak berpengaruh positif dan signifikan terhadap MSI bank syariah di Indonesia

$\mathrm{Ha}_{2}$ : iB-VAIC berpengaruh positif dan signifikan terhadap kinerja MSI bank syariah di Indonesia

Kriteria penarikan keputusan dari hipotesis adalah dengan membandingkan nilai hitung dengan nilai t-tabel $(0.05=$ 1.960). Pengujian hipotesis tersebut adalah:

1. Jika nilai t-hitung < nilai t-tabel, maka Ho diterima

2. Jika nilai $\mathrm{t}$ hitung $\geq$ nilai t-tabel, maka Ho ditolak dan Ha diterima.
Hasil dan Pembahasan

Analisis Deskriptif

1. Tingkat ICG Disclosure Bank Umum Syariah di Indonesia

Pengungkapan ICG ditentukan dengan skoring terhadap item-item pengungkapan pada laporan tahunan masingmasing bank. Pengungkapan ICG pada perbankan syariah di Indonesia disajikan pada Tabel 3 dibawah ini. Pengungkapan ICG pada bank syariah di Indonesia cukup baik dengan skor sebesar 55.39\%. Hal tersebut menggambarkan bahwa terjadi peningkatan tata kelola BUS di Indonesia dari tahun 2010 ke 2017. Menurut El Junusi (2012), implementasi pengungkapan ICG (terutama komponen sharia governance) diharapkan mampu meningkatkan reputasi dan kepercayaan nasabah terhadap BUS di Indonesia. 
Tabel 3

ICG Disclosure Bank Umum Syariah di Indonesia Periode Tahun 2013-2017

\begin{tabular}{ccccccc}
\hline $\begin{array}{c}\text { Bank Umum } \\
\text { Syariah }\end{array}$ & $\mathbf{2 0 1 3}$ & $\mathbf{2 0 1 4}$ & $\mathbf{2 0 1 5}$ & $\mathbf{2 0 1 6}$ & $\mathbf{2 0 1 7}$ & Rata-rata \\
\hline BCA & 0.531 & 0.544 & 0.512 & 0.512 & 0.512 & $\mathbf{0 . 5 2 2}$ \\
BMS & 0.481 & 0.481 & 0.513 & 0.513 & 0.530 & $\mathbf{0 . 5 0 3}$ \\
BJBS & 0.489 & 0.508 & 0.517 & 0.517 & 0.517 & $\mathbf{0 . 5 1 0}$ \\
BNIS & 0.669 & 0.688 & 0.679 & 0.679 & 0.679 & $\mathbf{0 . 6 7 9}$ \\
BMI & 0.719 & 0.746 & 0.763 & 0.763 & 0.763 & $\mathbf{0 . 7 5 1}$ \\
BRIS & 0.586 & 0.554 & 0.582 & 0.600 & 0.600 & $\mathbf{0 . 5 8 4}$ \\
BSB & 0.496 & 0.519 & 0.515 & 0.515 & 0.515 & $\mathbf{0 . 5 1 2}$ \\
BSM & 0.740 & 0.758 & 0.713 & 0.713 & 0.713 & $\mathbf{0 . 7 2 7}$ \\
BVS & 0.496 & 0.519 & 0.515 & 0.515 & 0.515 & $\mathbf{0 . 5 1 2}$ \\
MSI & 0.577 & 0.572 & 0.572 & 0.572 & 0.572 & $\mathbf{0 . 5 7 3}$ \\
BPS & 0.543 & 0.569 & 0.516 & 0.516 & 0.516 & $\mathbf{0 . 5 3 2}$ \\
Rata-rata & $\mathbf{0 . 5 7 5}$ & $\mathbf{0 . 5 8 7}$ & $\mathbf{0 . 5 8 1}$ & $\mathbf{0 . 5 8 3}$ & $\mathbf{0 . 5 8 5}$ & $\mathbf{0 . 5 8 2}$ \\
\hline
\end{tabular}

Sumber : Data penelitian diolah (2018)

Nilai ICG dalam penelitian ini lebih tinggi dibandingkan dengan pengungkapan ICG yang dilaporkan oleh Darmadi (2013). Dalam penelitiannya, Darmadi melaporkan bahwa pengungkapan ICG pada 11 bank syariah di Indonesia pada periode tahun 2010 hanya sebesar 52 persen. Hasil penelitian lainnya yang tentang pengungkapan ICG antara lain Abdullah, Percy dan Stewart (2015) pengungkapan ICG pada 67 bank syariah di negara GCC tahun 2009 hanya 37\%; Sulaiman, Majid dan Arifin (2015) pengungkapan CG pada 16 bank syariah di Malaysia tahun 2009 sebesar 51\%; sedang penelitian terbaru Srairi, (2015) hanya 54\% tingkat pengungkapan ICG bank syariah di GCC.

BMI dan BSM sebagai bank syariah tertua dan terbesar di Indoneia menjadi bank syariah dengan skor ICG tertinggi yaitu $70.83 \%$ dan $68.83 \%$. Tingginya pengungkapan ICG pada kedua BUS tersebut dikontribusi oleh tingginya skor pengungkapan kategori General Governance (GG) dibandingkan pengungkapan kategori Shariah Governance (SG). Tingginya skor pengungkapan ICG di Indonesia disebabkan beberapa faktor diantaranya adalah 11 bank syariah yang dijadikan sampel dalam penelitian ini seluruhnya secara konsisten mengungkapkan laporan GCG pada annual report selama periode 2013-2107. Selain itu, di Indonesia sudah ada regulasi khusus terkait GCG bank syariah, diantaranya adalah Undang-Undang No. 21 Tahun 2008 tentang Perbankan Syariah dan Peraturan Bank Indonesia No.11/33/PBI/2009 tentang Pelaksanaan GCG bagi Bank Umum Syariah dan Unit Usaha Syariah.

\section{Islamic Banking Value Added Intellectual Coefficient (iB-VAIC)}

iB-VAIC merupakan representasi dari penciptaan nilai tambah dengan memanfaatkan IC secara efisien. iB-VAIC dihitung berdasarkan jumlah antara iBVACA, iB-VAHU dan iB-STVA. Hasil perhitungan kinerja IC berdasarkan model iB-VAIC disajikan pada Tabel 4.4 dibawah ini. Dari hasil perhitungan Tabel 4.2 diperoleh bahwa rata-rata nilai iB-VAIC BUS di Indonesia dari tahun 2013 - 2017 berada pada tingkat Top Performers (TP), kecuali pada tahun 2016 yang berada pada tingkat GoodPerformers (GP). Hal ini menggambarkan bahwa BUS di Indonesia selama 5 tahun terakhir dapat mempertahankan performanya dengan baik. 
Nilai iB-VAIC tertinggi berada pada tahun

2016

sebesar

2.735 .

2015 sebesar 3.655 dan terendah pada tahun

Tabel 4

Rata-rata Nilai iB-VAIC Bank Umum Syariah (BUS) dari Tahun 2013-2017

\begin{tabular}{lccccccc}
\hline \multicolumn{1}{c}{ BUS } & $\mathbf{2 0 1 3}$ & $\mathbf{2 0 1 4}$ & $\mathbf{2 0 1 5}$ & $\mathbf{2 0 1 6}$ & $\mathbf{2 0 1 7}$ & Rata-rata & Kategori \\
\hline BCAS & 1.895 & 2.034 & 1.923 & 2.097 & 2.245 & 2.039 & GP \\
BMS & 4.298 & 3.479 & 3.181 & 2.717 & 2.291 & 3.193 & TP \\
BJBS & 1.763 & 0.314 & 5.007 & 3.626 & 4.177 & 2.977 & GP \\
BNIS & 3.644 & 4.014 & 4.607 & 4.641 & 5.090 & 4.399 & TP \\
BMI & 3.231 & 1.866 & 1.981 & 1.521 & 1.229 & 1.966 & CP \\
BRIS & 3.618 & 3.057 & 3.383 & 4.820 & 4.941 & 3.964 & TP \\
BSB & 2.268 & 1.613 & 2.260 & -2.089 & 1.216 & 1.053 & BP \\
BSM & 3.440 & 3.056 & 3.620 & 3.392 & 4.166 & 3.535 & TP \\
BVS & 4.282 & 4.746 & 5.075 & 3.674 & 5.829 & 4.721 & TP \\
MSI & 5.724 & 5.747 & 5.840 & 3.117 & 5.024 & 5.091 & TP \\
PBS & 2.400 & 4.382 & 3.325 & 2.566 & 2.133 & 2.961 & GP \\
Rata-rata & 3.324 & 3.119 & 3.655 & 2.735 & 3.486 & $\mathbf{3 . 2 6 4}$ & TP \\
Kategori & TP & TP & TP & GP & TP & TP & \\
\hline
\end{tabular}

Sumber : Data penelitian diolah (2018)

Jika dilihat kategori iB-VAIC, maka terdapat 6 (enam) BUS yang termasuk dalam kategori Top performers (TP) yaitu BMS, BNIS, BRIS, BSM, BVS dan MSI. Sedangkan yang termasuk dalam kategori Good performers (GP) berjumlah 3 (tiga) BUS yaitu BCAS, BJBS dan PBS, sedangkan sisanya termasuk ke dalam Common performers (CP) yaitu BMI dan Bad performers (BP) yaitu BSB. MSI merupakan BUS dengan nilai iB-VAIC tertinggi yaitu sebesar 5.091, sedangkan BSB adalah BUS dengan nilai iB-VAIC terendah yaitu senilai 1.053 .

\section{Tingkat MSI Performane Bank Umum Syariah}

Penentuan peringkat berdasarkan tingkat MSI dilakukan setelah menjumlahkan indikator kinerja MSI dari tujuan pertama sampai dengan tujuan ketiga. Berikut ini merupakan tabel Indeks MSI performancebeserta peringkat dari Bank Umum Syariah (BUS) periode 2013-2017.

Tabel 5

Tingkat MSI PerformanceBank Umum Syariah (BUS) Periode Tahun 2013 - 2017

\begin{tabular}{lllllcc}
\hline No & $\begin{array}{c}\text { Bank } \\
\text { Umum } \\
\text { Syariah }\end{array}$ & IK-T1 & IK-T2 & IK-T3 & $\begin{array}{c}\text { Tingkat MSI } \\
\text { Performance }\end{array}$ & Peringkat \\
\hline 1 & BCA & 0.0016 & 0.2374 & 0.1005 & 0.3394 & 2 \\
2 & BMS & 0.0006 & 0.1740 & 0.0758 & 0.2504 & 9 \\
3 & BJBS & 0.0004 & 0.1596 & 0.0510 & 0.2109 & 11 \\
4 & BNIS & 0.0061 & 0.1951 & 0.0499 & 0.2511 & 8 \\
5 & BMI & 0.0031 & 0.2258 & 0.0687 & 0.2976 & 6 \\
6 & BRIS & 0.0025 & 0.2096 & 0.0876 & 0.2997 & 5 \\
7 & BSB & 0.0037 & 0.2319 & 0.0724 & 0.3080 & 3 \\
\hline
\end{tabular}




\begin{tabular}{clllllc}
\hline 8 & BSM & 0.0020 & 0.1993 & 0.0582 & 0.2595 & 7 \\
9 & BVS & 0.0043 & 0.2204 & 0.0803 & 0.3050 & 4 \\
10 & MSI & 0.0027 & 0.1304 & 0.0821 & 0.2152 & 10 \\
11 & PBS & 0.0022 & 0.2638 & 0.0857 & 0.3516 & 1 \\
\hline
\end{tabular}

Sumber: Data penelitiann diolah (2018)

Berdasarkan Tabel 5, BNIS menjadi yang terbaik dalam pelaksanaan tujuan pertama (mendidik individu), PBS menjadi yang terbaik dalam pelaksanaan tujuan kedua (menegakkan keadilan), dan BCAS menjadi yang terbaik dalam pelaksanaan tujuan ketiga (mendorong kesejahteraan). Secara umum kinerja MSI performance PBS menjadi yang terbaik selama periode 20132017. Peringkat kedua dan ketiga adalah BCAS dan BSB.

\section{Hasil Analisis Model SEM-PLS}

Analisis kuantitatif bertujuan untuk menguji hipotesis yang diusulkan dalam penelitian. Metode analisis data yang digunakan untuk pengujian dalam penelitian ini adalah Partial Least Square (PLS) dengan menggunakan Smart PLS. Teksnik pengolahan data dengan menggunakan metode SEM berbasis PLS memerlukan 2 tahapan dalam menilai Fit Model dari sebuah model penelitian Ghozali (2014). Tahaptahap tersebut adalah sebagai berikut:

\section{Uji Outer Model : Validitas dan Reliabilitas}

Terdapat tiga kriteria di dalam penggunaan teknik analisa data dengan SmartPLS untuk menilai outer model yaitu Convergent Validity diukur dari nilai outer loading, Discriminant Validity yang diukur dengan nilai cross loading atau dengan cara melihat nilai korelasi setiap variabel, dan Composite Reliability atau $\mathrm{CR}$ untuk mengukur tingkat reliabilitas.

\section{a. Convergent validity}

Convergent validity merupakan tingkatan sejauh mana hasil pengukuran suatu konsep menunjukkan korelasi positif dengan hasil pengukuran konsep lain yang secara teoritis harus berkorelasi positif. Dalam evaluasi Convergent Validity dari pemeriksaan individual item reliability, dapat dilihat dari nilai standarized loading factor. Suatu indikator dikatakan mempunyai reabilitas yang baik, jika nilai outer loading dapat ditolerir hingga 0.500 dan nilai dibawah 0.500 dapat dihilangkan dari analisis (Ghozali, 2014. Hasil loading item pada outer model dapat dilihat dari gambar model dan tabel sebagai berikut. 
Gambar 2

Outer Model (Struktur 2)

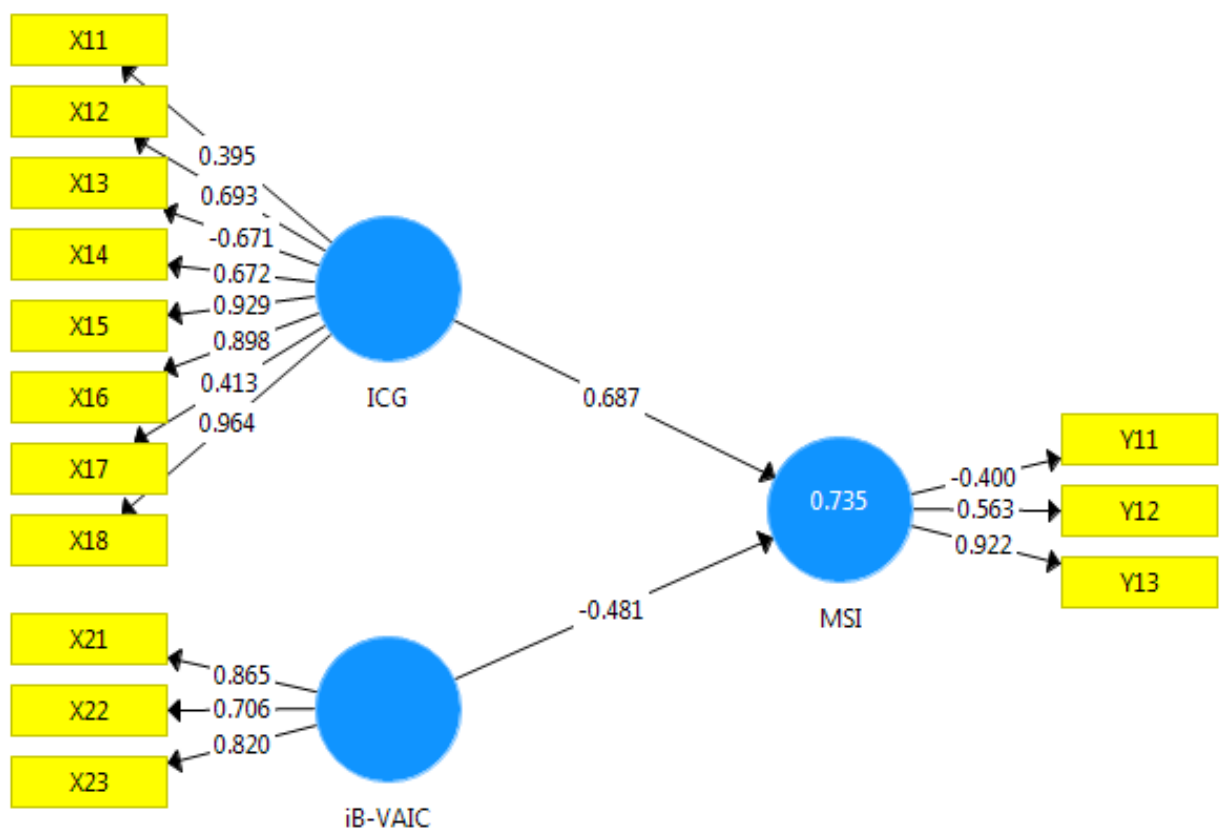

Sumber : Data penelitian diolah (2018)

Gambar diatas menunjukkan nilai Ketentuan dikatakan item valid jika nilai dari validitas pada masing-masing konstruk masing-masing outer loading tersebut $\geq$ terhadap itemnya. Nilai pada masing-masing 0.500 dan mengelompok pada item lainya dari konstruk ke item merupakan nilai dari yang merupakan pengukuran dari masingouter loading masing-masing item. masing konstruk.

Tabel 6

Hasil Uji Convergent Validity - Outer Loadings

\begin{tabular}{lcccc}
\hline & ICG (X1) & iB-VAIC (X2) & MSI (Y) & Ket \\
\hline $\mathbf{X 1 1}$ & 0.395 & & & Tidak Valid \\
$\mathbf{X 1 2}$ & 0.693 & & & Valid \\
$\mathbf{X 1 3}$ & -0.671 & & & Tidak Valid \\
$\mathbf{X 1 4}$ & 0.672 & & & Valid \\
$\mathbf{X 1 5}$ & 0.929 & & & Valid \\
$\mathbf{X 1 6}$ & 0.898 & & & Valid \\
$\mathbf{X 1 7}$ & 0.413 & & & Tidak Valid \\
$\mathbf{X 1 8}$ & 0.964 & & & Valid \\
$\mathbf{X 2 1}$ & & 0.865 & & Valid \\
$\mathbf{X 2 2}$ & & 0.706 & -0.400 & Valid \\
$\mathbf{X 2 3}$ & & 0.820 & 0.563 & Valid \\
Y11 & & & 0.922 & Valid \\
Y12 & & & & Valid \\
$\mathbf{Y 1 3}$ & & & \\
\hline
\end{tabular}

Sumber : data penelitian diolah (2018) 
Berdasarkan Tabel 6 diatas hasil bersifat tidak valid. Berdasarkan hasil diperoleh bahwa indikator variabel yang analisis tersebut, maka perlu dilakukan valid untuk variabel konstruk eksogen ICG pengujian ulang untuk mendapatkan variabel adalah X12, X14, X15, X16 dan X18, valid dengan cara menghapus indikator sedangkan yang lainnya tidak valid. Untuk variabel yang nilai outer loading-nya kurang variabel laten iB-VAIC, indikator variabel dari 0.500. Hasil pengujian ulang tersebut X22, X23, X24 dan X25 bersifat valid. Pada seperti yang disajikan pada Gambar 3 variabel konstruk endogan, hanya Y11 yang dibawah ini.

Gambar 3

Outer Model (Struktur 2)

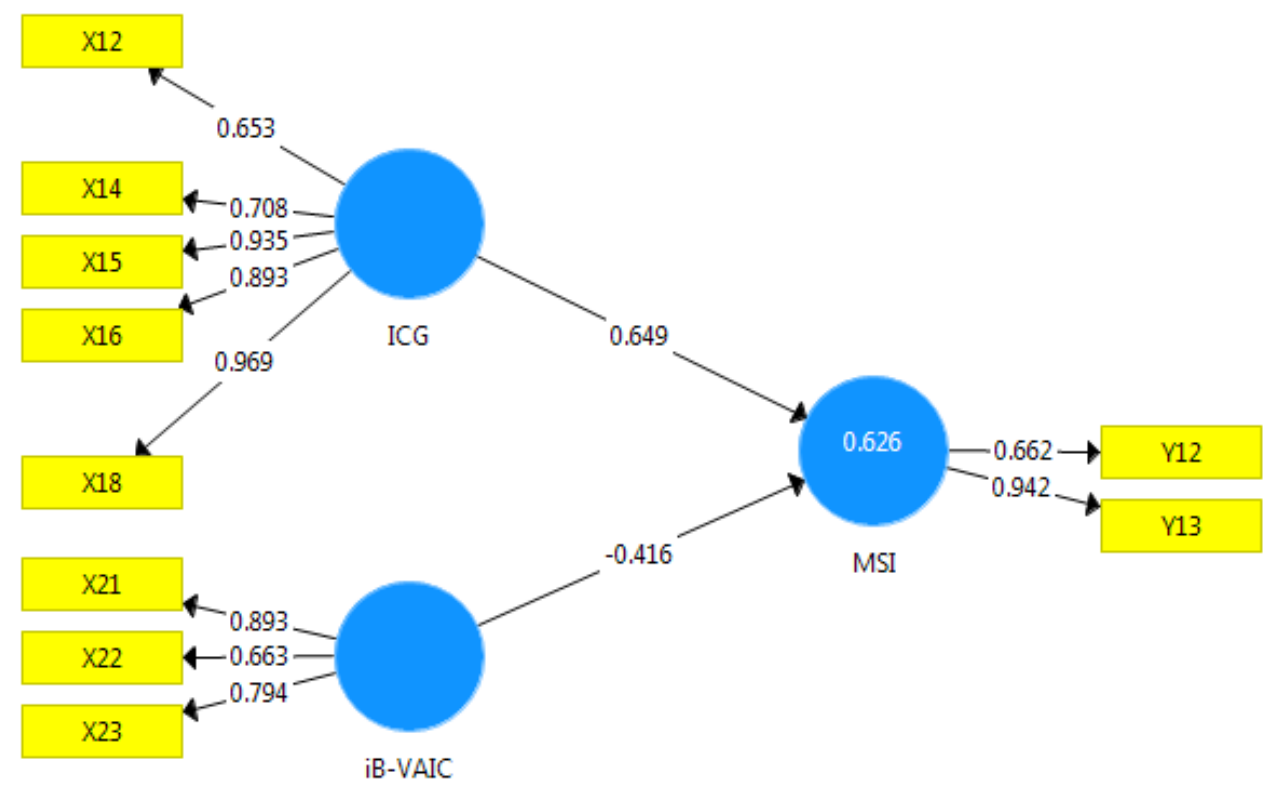

Sumber : data penelitian diolah (2018)

Gambar diatas menunjukkan nilai masing-masing dari konstruk ke item validitas pada masing-masing konstruk merupakan nilai dari outer loading masingterhadap itemnya yang telah mengalami masing item. analisis ulang dari struktur 1. Nilai pada

Tabel 7

Hasil Uji Convergent Validity - Outer Loadings

\begin{tabular}{ccccc}
\hline & ICG $(\mathbf{X 1})$ & iB-VAIC (X2) & MSI (Y) & Ket \\
\hline $\mathbf{X 1 2}$ & 0.653 & & Valid \\
$\mathbf{X 1 4}$ & 0.708 & & Valid \\
$\mathbf{X 1 5}$ & 0.935 & & Valid \\
$\mathbf{X 1 6}$ & 0.893 & & Valid \\
$\mathbf{X 1 8}$ & 0.969 & & Valid \\
$\mathbf{X 2 2}$ & & 0.893 & Valid \\
$\mathbf{X 2 3}$ & & 0.663 & Valid \\
\hline
\end{tabular}




\begin{tabular}{llll}
\hline $\mathbf{X 2 4}$ & 0.794 & & Valid \\
Y12 & & 0.662 & Valid \\
Y13 & & 0.942 & Valid \\
\hline
\end{tabular}

Sumber : data penelitian diolah (2018)

Berdasarkan Tabel 7 diatas hasil diperoleh bahwa keseluruhan item indikator pada variabel ICGD, ICSR, kinerja keuangan dan disiplin pasar memiliki nilai di atas 0.500 sehingga outer loading bersifat valid. Artinya seluruh variabel konstruk layak untuk dilakukan pengujian selanjutnya.

b. Discriminant Validity
Discriminant validity dilakukan untuk memastikan bahwa setiap konsep darimasing-masing variabel laten berbeda dengan variabel lainnya. Model dikatakan mempunyai discriminant validity yang baik jika nilai Avarage Varience Extracted ( $A V E$ ) dengan nilai $(\geq 0.500)$ dan Communaly $(\geq$ $0.500)$. Hasil pengujian discriminant validity dengan nilai AVE berikut:

Tabel 8

Hasil Uji Discriminant Validity - Nilai AVE

\begin{tabular}{lccc}
\hline \multicolumn{1}{c}{ Variabel } & AVE & Kriteria & Ket. \\
\hline ICG (X1) & 0.708 & 0.500 & Valid \\
iB-VAIC (X2) & 0.623 & 0.500 & Valid \\
MSI (Y) & 0.663 & 0.500 & Valid \\
\hline
\end{tabular}

Sumber : data penelitian diolah (2018)

Dari hasil tabel di atas dapat jelaskan data memiliki discriminant validity yang bahwa dari hasil ketiga variabel memiliki baik. Selanjutnya dilakukan analisis validitas nilai AVE $\geq 0.500$ sehingga dapat dikatakan dengan nilai communality.

\section{Tabel 9}

Hasil Uji Validitas Nilai Communality

\begin{tabular}{lccc}
\hline \multicolumn{1}{c}{ Variabel } & Communality & Kriteria & Ket. \\
\hline ICG (X1) & 0.922 & 0.500 & Valid \\
iB-VAIC (X2) & 0.830 & 0.500 & Valid \\
MSI (Y) & 0.792 & 0.500 & Valid \\
\hline
\end{tabular}

Sumber : data penelitian diolah (2018)

Berdasarkan Tabel 9 dapat diketahui bahwa seluruh nilai communality dari seluruh variabel penelitian $\geq 0.500$ yang berarti semua variabel dinyatakan baik. Hal ini menunjukkan seluruh item pada variabel valid berdasarkan seluruh kriteria pengukuran validitas.

\section{c. Uji Reliabilitas Cronbach's Alpha}

Kriteria reliabilitas juga dapat dilihat dari nilai Cronbach's Alpha suatu variabel dari masing-masing variabel. Cronbach's Alpha, item yang mengukur konsistensi internal dari item pembentuk variabel. Nilai batas untuk tingkat reliabilitas $\geq 0.700$, hasil uji reliabilitas sebagai berikut: 
Tabel 10

Hasil Uji Reliabilitas

\begin{tabular}{lccc}
\hline \multicolumn{1}{c}{ Variabel } & Composite Reliability & Kriteria & Ket. \\
\hline ICG (X1) & 0.893 & 0.700 & Reliabel \\
iB-VAIC (X2) & 0.743 & 0.700 & Reliabel \\
MSI (Y) & 0.768 & 0.700 & Reliabel \\
\hline
\end{tabular}

Sumber : data penelitian diolah (2018)

Hasil analisis uji reliabilitas menginformasikan bahwa seluruh variabel memenuhi Cronbach's Alpha $\geq 0,700$ sudah memenuhi kriteria reliabel dan layak untuk digunakan dalam penelitian selanjutnya. Berdasarkan dari hasil evaluasi secara keseluruhan, baik convergent validity, discriminant validity, danuji reliability dengan Cronbach's Alpha, yang telah dipaparkan di atas, dapat disimpulkan bahwa item pernyataan sebagai pengukur variabel merupakan pengukur yang valid dan reliabel.

\section{Uji Inner Model}

Pengujian inner model dalam penelitian ini dilakukan dengan melihat nilai $\mathrm{R}$ square dari model struktural. Hasil perhitungan nilai $\mathrm{R}$ square merupakan perhitungan besarnya pengaruh variabel independen terhadap variabel dependen. Semakin besar angka $R$-square menunjukkan semakin besar variabel independen tersebut dapat menjelaskan variabel dependen, sehingga semakin baik persaman struktural. Dalam penelitian ini nilai $\mathrm{R}$ square merupakan perhitungan besarnya pengaruh ICG dan iB-VAIC terhadap MSI. Berikut disajikan hasil pengujian $\mathrm{R}$ square.

Tabel 11

Hasil R Square Model SEM-PLS

\begin{tabular}{lr}
\hline Variabel Konstruk & $R$ square \\
\hline ICG (X1) & 0.626 \\
iB-VAIC (X2) & 0.533 \\
\hline
\end{tabular}

Sumber : data penelitian diolah (2018)

Berdasarkan Tabel 11 diatas diperoleh nilai R square ICG terhadap MSI adalah sebesar 0.626 atau $62.6 \%$ variabel ICG mampu menjelaskan variabel MSI, sedangkan sisanya $27.4 \%$ dipengaruhi oleh variabel lain. Nilai $\mathrm{R}$ Square iB-VAIC terhadap MSI adalah sebesar 0.533 atau $53.3 \%$ variabel iB-VAIC mampu menjelaskan variabel MSI, sedangkan sisanya $46.7 \%$ dipengaruhi oleh variabel lain.

\section{Pengujian Hipotesis}

Pengujian hipotesis dilihat dari nilai jalur (t-hitung) pada model yang terbentuk untuk selanjutnya dibandingkan dengan nilai t-tabel pada tingkat kesalahan yang digunakan $(\alpha=0.05)$. Hasil pengujian hipotesis dapat dilihat dari gambar model sebagai 


\section{Gambar 4 \\ Inner Model (Uji Hipotesis Bootstrapping)}

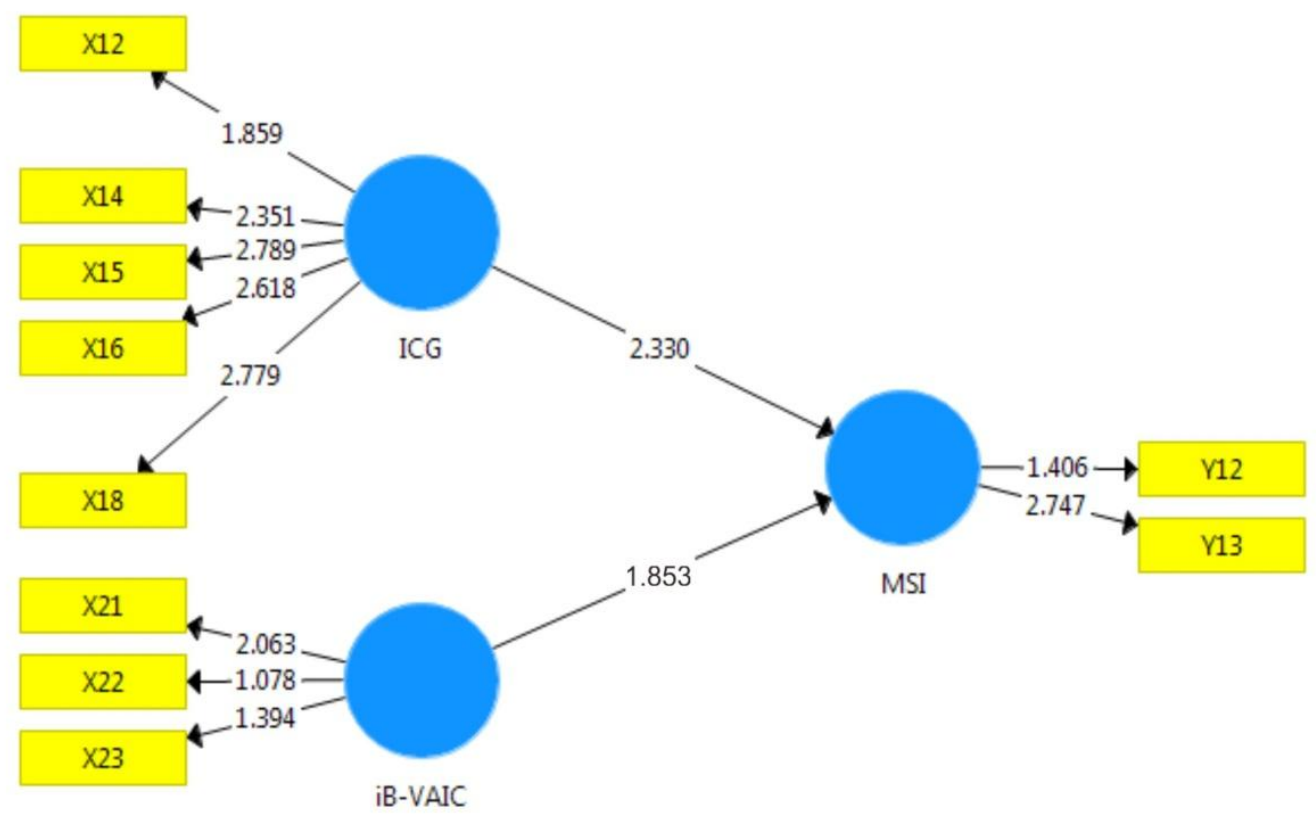

Sumber : data penelitian diolah (2018)

Dari Gambar 4 dapat dijelaskan bahwa covariabel pengukuran item dipengaruhi oleh konstruk laten atau mencerminkan variasi dari konstruk unidimensional dengan beberapa anak panah dari konstruk ke item. Dalam model tersebut terdapat dua variabel konstruk eksogen yaitu ICG dan iB-VAIC dan satu variabel konstruk endogen yaitu MSI. Adanya pengaruh yang signifikan variabel konstruk eksogen terhadap variabel konstruk dependenditunjukkan dengan membandingkannilai $\mathrm{t}$ hitung $>\mathrm{t}$-tabel (Ho ditolak). Hasil analisis jalur dengan teknik analisis SEM-PLSdapat dilihat pada tabel berikut.

Tabel 12 Hasil Analisis Jalur

\begin{tabular}{lccc}
\hline \multicolumn{1}{c}{ Variabel } & Koefisien & t-hitung & Ket. \\
\hline ICG (X1) ke MSI (Y) & 0.649 & 2.330 & Signifikan \\
iB-VAIC (X2) ke MSI (Y) & 0.416 & 1.853 & Signifikan \\
\hline
\end{tabular}

Sumber : data penelitian diolah (2018)

1. Pengaruh ICG terhadap terhadap MSI bank syariah di Indonesia

Hasil analisis pada tabel di atas dapat diketahui bahwa nilai t statistik pengaruh ICG terhadap MSI adalah 2.330 dan nilai t-tabel signifikansi 5\% adalah 1.960. Oleh karena nilai $t$ statistik lebih besar dari t-tabel $(2.330$ $>$ 1.960), maka ICG berpengaruh signifikan terhadap MSI. Nilai koefisien ICG yaitu 0.649 yang diartikan setiap kenaikan 1 satuan nilai pengungkapan ICG akan meningkatkan MSI sebesar 0.649. Hal ini berarti bahwa ICG berpengaruh positif dan signifikan terhadap MSI bank syariah di Indonesia (Hipotesis Ho1 di tolak).

Temuan ini sejalan dengan hasil survei yang dilakukan oleh Chapra dan 
Ahmed, (2002), terhadap nasabah deposito bank syariah di Bahrain, Sudan, dan Banglades menunjukkan bahwa mayoritas nasabah deposito akan memindahkan dana mereka ke bank syariah lain jika mengetahui pihak bank menjalankan bisnis mereka tidak sesuai dengan prinsip syariah. Pelaksanaan prinsip syariah yang baik merupakan bagian dari pelaksanaan ICG yang baik pada bank syariah.

Menurut Ernawan (2018), ICG berpengaruh positif dan siginifikan terhadap MSI pada bank syariah di Indonesia. Penelitian lainnya yang selaras antara lain Rama dan Novela (2015) dan Srairi (2015). Penerapan ICG pada bank syariah mencakup aspek tatakelola perusahaan dan pemenuhan terhadap kepatuhan prinsip-prinsip syariah. ICG yang baik mencerminkan seluruh elemen bank syariah berjalan dengan sesuai dengan prosedur serta hukum yang berlaku dan kepatuhan terhadap prinsip syariah. Sehingga roda usaha perusahaan berjalan dengan baik dan meningkatkan kinerja keuangan. Salah satu elemen penting dalam tatakelola bank syariah yang tidak terdapat pada bank konvensional adalah DPS. DPS harus mampu menjalankan fungsinya dalam mengawasi kepatuhan aspek syariah, karena sebaik apapun kinerja keuangan bank syariah tapi melanggar prinsip syariah, maka tidak bernilai apa-apa dalam perspektif Islam.

Penelitian Safieddine

(2009)

mengenai pengaruh praktik tata kelola perusahaan terhadap kinerja perusahaan perbankan syariah yang beroperasi di lima Negara yaitu Arab Saudi, Kuwait, Qatar, Bahrain dan Uni Emirat Arab. Hasilnya menyatakan bahwa tata kelola perusahaan yang baik berpengaruh positif terhadap semakin meningkatkanya kinerja perusahaan perbankan syariah. Bank syariaha yang indeks CG-nya dalam kategori tinggi, secara signifikan beroperasi lebih efisien dan mampu mencapai tingkat pertumbuhan penjualan dan laba tertinggi. Dan sebaliknya, bank syariah yang indeks CG-nya rendah signifikan kinerja keuanganya juga rendah.

\section{Pengaruh iB-VAIC terhadap terhadap MSI bank syariah di Indonesia}

Hasil analisis pada tabel di atas dapat diketahui bahwa nilai t statistik pengaruh iB-VAICterhadap MSI adalah 1.853dan nilai t-tabel signifikansi $5 \%$ adalah 1.960. Oleh karena nilai t statistik lebih besar dari t-tabel $(1.853>1.960)$, maka dapat dikatakan iB-VAIC berpengaruh signifikan terhadap kinerja keuangan. Nilai koefisien iB-VAIC yaitu 0.416 yang diartikan setiap kenaikan 1 satuan nilai pengungkapan iB-VAIC akan meningkatkan MSI sebesar 0.416. Hal ini berarti bahwa iB-VAIC berpengaruh positif dan signifikan terhadap MSI bank syariah di Indonesia (Hipotesis Hol di tolak).

Sukimin (2018), menyampaikan bahwa iB-VAIC berpengaruh positif dan signifikan terhadap kinerja keuangan bank syariah. Selain itu, hasil penelitian ini sejalan dengan hasil penelitian oleh Firer dan Williams (2003); Tan et al. (2007); Dewanata, Hamidah dan Ahmad (2016) yang menghasilkan bahwa variabel IC memiliki pengaruh positif dan signifikan terhadap kinerja keuangan bank syariah.Andraeny dan Putri (2017), variabel IC dan dewan pengawas syariah (sharia supervisory board) memiliki pengaruh positif dan signifikan terhadap kinerja keuangan bank syariah. Jika perusahaan mengelola modal intelektualnya (IC) dengan baik, maka berdampak pada nilai tambah yang dapat menciptakan keunggulan kompetitif bagi perusahaan. Hal tersebut sejalan dengan hasil penelitian Hidayanti 
(2017) dan Prasetya dan Mutmainah (2011) yang menunjukkan bahwa IC berpengaruh signifikan terhadap kinerja keuangan dan dapat digunakan untuk memprediksi kinerja keuangan di masa depan. Penelitian Prasetya dan Mutmainah (2011) membuktikan penelitian sebelumnya yang dilakukan Chen et al. (2005) dengan menggunakan data dari perusahaan listing di Taiwan, bahwa intellectual capital berpengaruh positif terhadap kinerja perusahaan, dan dapat digunakan sebagai indikator kinerja keuangan masa depan.

Sedangkan penelitian yang dilakukan oleh Ulum (2007) menguji pengaruh intellectual capital terhadap kinerja keuangan perusahaan perbankan, hasilnya VAIC berpengaruh positif dan signifikan terhadap kinerja keuangan perbankan syariah. Rasionalisasi yang dapat diberikan untuk menjelaskan temuan ini adalah (1) value added terbesar yang dimiliki perusahaan dihasilkan oleh efisiensi dari human capital. Artinya, perbankan di Indonesia telah berhasil "memanfaatkan" dan memaksimalkan keahlian, pengetahuan, jaringan, dan olah pikir karyawannya untuk menciptakan nilai bagi perusahaan. (2) karyawan telah berhasil ditempatkan dan menempatkan diri dalam posisi sebagai stakeholders perusahaan, sehingga mereka memaksimalkan intellectual ability-nya untuk menciptakan nilai bagi perusahaan. Hal ini dibuktikan dengan adanya value creation yang dilakukan oleh karyawan meskipun dengan penerimaan (gaji, biaya pelatihan, dsb.) yang tidak maksimal dari perusahaan.

\section{Penutup}

Berdasarkan hasil analisis dan pembahasan dapat disimpulkan bahwa (1) variabel ICG berpengaruh positif dan signifikan terhadap MSI bank syariah di
Indonesia. Nilai koefisien ICG sebesar 0.649 artinya setiap kenaikan 1 satuan nilai pengungkapan ICG akan meningkatkan MSI sebesar 0.649. Penerapan ICG yang mencakup aspek tata kelola perusahaan dan pemenuhan terhadap kepatuhan prinsipprinsip syariahakan berdampak pada meningkatnya kinerja keuangan bank syariah. (2) Variabel IC (iB-VAIC) berpengaruh positif dan signifikan terhadap MSI bank syariah di Indonesia. Nilai koefisien iB-VAIC yaitu 0.416 yang diartikan setiap kenaikan 1 satuan nilai pengungkapan iB-VAIC akan meningkatkan MSI sebesar 0.416. Optimalisasi IC (customer, human dan structural capital) akan berdampak pada peningkatan pencapaian tujuan maqashid syariah.

\section{Daftar Pustaka}

Abdullah, W. A., Percy, M., \& Stewart, J. (2013). Shari'ah disclosures in Malaysian and Indonesian Islamic banks The Shari'ah governance system. Journal of Islamic Accounting and Business Research, Vol. 4 No. 2, 100-131.

Andraeny dan Putri. (2017). Islamicity Financial Performance Index in Indonesian Islamic Banks. Journal of Economics and Business.

Arikunto, S. (2010). Prosedur Penelitian Suatu Pendekatan Praktik (14 ed.). Jakarta: PT Rineka Cipta.

Asrori. (2014).Implementai Islamic Corporate Governance dan Implikasinya terhadap Kinerja Bank Syariah. Jurnal Dinamika Akuntansi Vol 6 No 1 Maret 2014.

Bontis, N, W.C.C. Keow, S. Richardson. (2000). "Intellectual Capital And Business Performance In Malaysian Industries". Journal of Intellectual Capital. Vol. 1 No. 1. pp. 85-100.

Chapra MU dan Ahmed H. (2002). Corporate Governance in Financial Institution. Occasional Paper. 
Chen, M.C., S.J. Cheng, Y. Hwang. (2005). An empirical investigation of the relationship between intellectual capital and firms' market value and financial performance. Journal of Intellectual Capital. Vol. 6 N0. 2. pp. 159-176.

Darmadi, S. (2013). Corporate governance disclosure in the annual report : An exploratory study on Indonesian Islamic banks. Humanomics, Vol.29 No.1, 4-23.

Dewanata, Hamidah dan Ahmad (2016). The Effect Of Intellectual Capital And Islamicity Performance Index to the Performance of Islamic Bank in Indonesia 2010- 2014 Periods. Jurnal Riset Manajemen Sains Indonesia (JRMSI) Vol 7, No. 2.

El-Junusi, Rahman. (2012). Membangun Kemitraan Antara Bank Syariah dan Nasabah Dengan Pendekatan Customer Relationship Management. Semarang.

Ernawan DA. (2018). Maqashid Syariah Index (MSI) Performance dan Islamic Corporate Governanve (ICG) Disclosure Perbankan Syariah di Indonesia. Universitas Padjajaran. Bandung.

Farook, S., Hassan, M. K., \& Clinch, G. (2012).Profit Distribution management by Islamic banks: An empirical investigation. The Quarterly Review of Economics and Finance, 52(3), 333-347.

Firer, S., and S.M. Williams. (2003). "Intellectual capital and traditional measures of corporate performance". Journal of Intellectual Capital. Vol. 4 No. 3. pp. 348-360.

Ghozali, Imam. (2014). Structural Equation Modeling, Metode Alternatif dengan Partial Least Square (PLS). Edisi 4. Semarang : Badan Penerbit Universitas Diponegoro.

Hidayanti HN. (2017). Pengaruh Penerapan Intellectual Capital dan Penerapan Islamic Corporate Governance Terhadap Kinerja Keuangan Bank
Umum Syariah di Indonesia Berdasarkan Islamicity Performance Index. UIN Jakarta. Jakarta.

Larbsh MM. (2015). Islamic Perspective of Corporate Governance. Acounting Department. Faculty of Economic and Commerce. Al-Asmarya Islamic University.

Maradita A. (2014). Karakteristik Good Corporate Governance Pada Bank Syariah dan Bank Konvensional. Yuridika : Volume 29 No 2, MeiAgustus.

Mohammed MO dan Dzuljastri AR. (2008).The Performance Measures of Islamic Banking Based on the Maqasid Framework. IIUM International Accounting Conference (INTAC IV) held at Putra Jaya Marroitt, 25 June 2008.

Mohammed, Mustafa Omar \& Taib, Fauziah Md. (2015). Developing Islamic Banking Performance Measures Based On Maqasid Al-Shari'ah Framework: Case of 24 Selected Banks, Journal of Islamic Monetary Economics and Finance, hal. 55-77.

Otoritas Jasa Keuangan [OJK]. (2018). Statistik Perbankan Indonesia Januari 2018.

Peraturan Bank Indonesia [PBI]. (2012). Nomor $\quad 14 / 26 / \mathrm{Pbi} / 2012$ Tentang Kegiatan Usaha Dan Jaringan Kantor Berdasarkan Modal Inti Bank. Bank Indonesia. Jakarta.

Prasetya DN dan Mutmainah S. (2010). Analisis Pengaruh Intellectual Capital Terhadap Islamicity Financial Performance Index Bank Syariah di Indonesia

Pulic, A. (1998). "Measuring the performance of intellectual potential in knowledge economy". Paper presented at the 2nd McMaster Word Congress on Measuring and Managing Intellectual Capital by the Austrian Team for Intellectual Potential.

Rama Ali dan Novella, Yella. (2015). Shariah Governance dan Kualitas 
Tata Kelola Perbankan Syariah. Signifikan, Vol. 4(2): 111-127.

Safieddine, A. (2009). Islamic Financial Institutions and Corporate Governance: New Insights for Agency Theory. Corporate Governance: An International Review, hal. 142-158.

Sawarjuwono, T. Kadir, P.A. (2003). "Intellectual Capital: Perlakuan, Pengukuran, dan Pelaporan (Sebuah Library Research)". Jurnal Akuntansi dan Keuangan. Vol. 5 No. 1. pp. 3557.

Solikhah, Badingatus, A. Rahman, dan Wahyu Merianto. (2010). "Implikasi Intellectual Capital terhadap Financial Performance, Growth dan Market Value ; Studi Empiris dengan Pendekatan Simplistic Specification". Jurnal Simposium Nasional Akuntansi XIII. Purwokerto.

Srairi, S. (2015). Corporate Governance Disclosure Practices and Performance of Islamic Banks in GCC Countries. Journal of Islamic Finance, Vol. 4 No. 2, 1-17.

Stewart, Thomas A. (1997). Intellectual Capital: The New Wealth of Organization, Doubleday/Currency. New York.
Sukimin DAR. (2018). Pengaruh Intellectual Capital dan Penerapan Good Governance BisnisSyariahterhadap Islamicity Financial Performance Index pada Bank Syariah di Indonesia. Universitas Padjajaran. Bandung.

Sulaiman, M., Majid, N. A., \& Arifin, N. M. (2015). Corporate Governance of Islamic Financial Institutions in Malaysia . Asian Journal of Business and Accounting, Vol.8 No.1, 65-93.

Tan, H.P., D. Plowman, P. Hancock. (2007). "Intellectual capital and financial returns of companies". Journal of Intellectual Capital. Vol. 8 No. 1. pp. 76-95.

Ulum I. (2007). "Pengaruh Intellectual Capital Terhadap Kinerja KeuanganPerusahaan Perbankan Di Indonesia". Thesis. Universitas Diponegoro.

Ulum I. (2009). Intellectual Capital: Konsep dan Kajian Empiris.Yogyakarta: Graha Ilmu

Umar H. (2007), Metode Penelitian Untuk Skripsi Dan Tesis Bisnis, Jakarta: PT. Raja Grafindo Persada.

Yamin S dan Kurniawan H. (2009). Structural Equation Modelling. Salemba Infotek. Jakarta. 